\title{
The relationship between EVA, MVA and leverage
}

JH de Wet

\section{Department of Financial Management University of Pretoria}

JH Hall

\section{Department of Financial \\ Management \\ University of Pretoria}

\begin{abstract}
It is generally believed that in order to maximise value for shareholders, companies should strive towards maximising MVA (and not necessarily their total market value). The best way to do so is to maximise the EVA, which reflects an organisation's ability to earn returns above the cost of capital. The leverage available to companies that incur fixed costs and use borrowed capital with a fixed interest charge has been known and quantified by financial managers for some time. The popularisation of EVA and MVA has opened up new possibilities for investigating the leverage effect of fixed costs (operational leverage) and interest (financial leverage) in conjunction with EVA and MVA, and for determining what effect changes in sales would have through leverage, not only on profits, but also on EVA and MVA. Combining a variable costing approach with leverage analysis and value analysis opens up new opportunities to investigate the effect of certain decisions on the MVA and the share price of a company. A spreadsheet model is used to illustrate how financial managers can use the leverage effects of fixed costs and the (fixed) cost of capital to maximise profits and also to determine what impact changes in any variable like sales or costs will have on the wealth of shareholders.
\end{abstract}

\section{Key words}

Economic Value Added (EVA)

Total degree of leverage (TDL)

Market Value Added (MVA)

EVA leverage

Degree of operating leverage (DOL)

Total leverage including EVA

Degree of financial leverage (DFL)

Weighted average cost of capital (WACC) 


\section{Introduction}

Few would argue that the most important financial goal of a business organisation should be to maximise the wealth of its shareholders. For a number of years now, accounting measures such as earnings, return on assets and return on equity have been criticised and found wanting as performance indicators leading to greater shareholder wealth (Johnson, Natarajan and Rappaport 1985; Rappaport 1986; Stewart 1991; Ehrbar 1998). The concept of value management resulted from a pursuit of the real drivers of value, and the performance measures Economic Value Added (EVA) and Market Value Added (MVA) are now known fairly well and used widely by companies all over the world.

The objective of this study is to link the cost management techniques of variable costing and cost-volume-profit analysis with the financial management techniques of leverage analysis and value analysis in order to determine how decisions or changes in inputs will affect the shareholder value. The study also introduces the leverage effect of the cost of equity as a new concept and illustrates how it reacts in conjunction with operating leverage and financial leverage to determine the total overall leverage of the company.

This new approach would be useful for decision-making purposes in assessing the impact, not only of different decision alternatives, but also of changes in internal factors like production costs or external factors like inflation and tax rates. The findings of this study could be of value to managers at all levels in a business organisation, but especially to financial managers. Existing shareholders and potential investors would also benefit from the findings of the study, but the company data needed as inputs for the model would not be available to them.

In this article EVA, MVA and leverage will be discussed briefly, followed by an illustration of the development and use of a spreadsheet model to extend the leverage analysis of profits to EVA and MVA. The leverage effect of the cost of equity on EVA and MVA is investigated. The initial hypothesis is that similar to fixed costs and interest, the cost of equity will also have a leverage effect on the profits (and EVA and MVA) of the business. It should be possible to quantify this leverage effect and to use it, together with the well-known operating leverage and financial leverage factors, to determine the total leverage for the company. Once the total leverage is determined, it would be possible to predict what effect any change in input will have on profits, EVA and MVA.

An attempt is made to derive a formula (given certain assumptions) to predict what effect a particular change in volume (sales) would have on EVA and MVA. Finally, the impact of different levels of operating and financial leverage on profits, EVA and MVA is evaluated. 


\section{The concepts of EVA, MVA and leverage}

\subsection{EVA and MVA}

A company's total market value is equal to the sum of the market value of its equity and the market value of its debt. In theory, this amount is what can be "taken out" of the company (i.e. when all shares are sold and debt is repaid) at any given time. The MVA is the difference between the total market value of the company and the economic capital (Firer 1995:57; Reilly and Brown 2003:591). The economic capital, also called invested capital (IC), is the amount that is "put into" the company and is basically the fixed assets plus the net working capital.

MVA = Market value of company - Invested Capital

From an investor's point of view, MVA is the best final measure of a company's performance. Stewart (1991:153) states that MVA is a cumulative measure of corporate performance and that it represents the stock market's assessment from a particular time onwards of the net present value of all a company's past and projected capital projects. MVA is calculated at a given moment, but in order to assess performance over time, the difference or change in MVA from one date to the next can be determined to see whether value has been created or destroyed.

EVA is an internal measure of performance that drives MVA. Stewart (1991:153) defines EVA as follows: “A company's EVA is the fuel that fires up its MVA." EVA takes into account the full cost of capital, including the cost of equity. The concept of EVA is a measure of economic profit and was popularised and originally trade-marked by Stern Stewart and Company in the 1980s.

The calculation of EVA is the same as that of the well-known "residual income" measure that has been used as a benchmark of divisional performance for some time. Horngren, Datar and Foster (2003:790) and Garrison, Noreen and Seal (2003:616) compare EVA to residual income and other performance measures and describe the growing popularity of EVA. EVA is calculated as follows:

$\mathrm{EVA}=(\mathrm{ROIC}-\mathrm{WACC}) \times \mathrm{IC}$

where

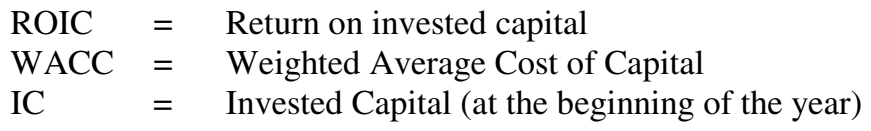

The return on IC minus the WACC is also called the "return spread". If the return spread is positive, it means that the company is generating surplus returns above its cost of capital, and this translates into higher MVA. Lehn and Makhija (1996:34) describe EVA as follows: "EVA and related measures attempt to improve on traditional accounting measures of performance by measuring the economic profits of an enterprise - after-tax operating profits less the cost of the capital employed to produce those profits." 
EVA can also be defined as the net operating profit before interest, but after tax (NOPAT) minus a capital charge based on the WACC multiplied by the IC:

$\mathrm{EVA}=$ NOPAT $-($ WACC $\times$ IC $)$

where

NOPAT $=$ net operating profit after tax

The link between MVA and EVA is that theoretically, MVA is equal to the present value of all future EVA to be generated by the company.

MVA $=$ present value of all future EVA

\section{Example}

Company $\mathrm{Z}$ has invested capital amounting to $\mathrm{R} 100 \mathrm{~m}$ at the beginning of the year. This is financed by $60 \%$ equity and $40 \%$ debt. The debt carries an interest rate of $12 \%$ before tax. The tax rate is $30 \%$ and the WACC is $15 \%$. The net income for the year before interest and tax is $\mathrm{R} 30 \mathrm{~m}$.

The return on invested capital after tax (ROIC) is $30 \mathrm{~m} / 100 \mathrm{~m} \times(1-$ tax rate of $30 \%)=21 \%$.

$$
\begin{aligned}
\text { EVA } & =(\text { ROIC }- \text { WACC }) \times \text { IC } \\
& =(21 \%-15 \%) \times \mathrm{R} 100 \mathrm{~m} \\
& =6 \% \times \mathrm{R} 100 \mathrm{~m} \\
& =\mathrm{R} 6 \mathrm{~m}
\end{aligned}
$$

Applying the second formula given for EVA, the result is the same:

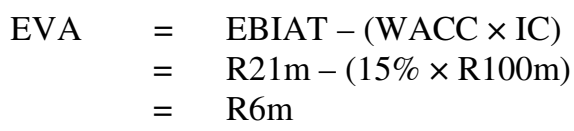

where

EBIAT $=$ Earnings before interest, after adjusted tax

If the future EVAs are expected to remain indefinitely at R6 million per year, the MVA can be calculated as follows:

$$
\begin{aligned}
\text { MVA } & =\mathrm{EVA} / \mathrm{WACC} \\
& =\mathrm{R} 6 \mathrm{~m} / 15 \% \\
& =\mathrm{R} 40 \mathrm{~m}
\end{aligned}
$$

It can be concluded that there are basically only three ways in which a company can increase its MVA (Stewart 1991:137; Ernst \& Young 1994:10; Firer 1995:57; Davidson 2003:49):

$\square$ By making new investments in projects with a positive return spread (positive EVA);

By expanding current projects earning a positive EVA; and 
By scaling down or eliminating projects that have a negative EVA.

If the company is not operating at optimal levels of financial gearing, changing the proportion of debt relative to equity can lower the WACC, so that the capital structure is closer to optimal. This will also unlock value for the company as a whole, including the shareholders.

Studies have shown that, compared to other accounting measures, MVA has by far the best correlation with Economic Value Added (EVA) (Stern 1993; Grant 1997). Further support for EVA has come from studies by Hall (1998), Gates (2000), Kramer and Peters (2001) and Hatfield (2002), while there has been some criticism, amongst others from Keef and Roush (2002) and Copeland (2002). MVA is also defined as the present value of all future EVAs the company will generate. It stands to reason that an organisation can maximise its MVA by maximizing its EVA (Stewart 1991; Weston and Copeland 1992; Copeland, Koller and Murrin 1996; Hawawini and Viallet 1999; Brealy and Myers 2000).

\subsection{Operational leverage, financial leverage and total leverage}

"Operational leverage" (Correia, Flynn, Uliana and Wormald 2003; Gitman 2000; Ross, Westerfield, Jordan and Firer 1999) refers to the effect that fixed costs have on the volatility (and risk) of profits, given fluctuations in sales. The degree of operating leverage (DOL) is calculated as follows:

DOL $=$ Contribution / Operating profit (after fixed costs)

The answer is a factor equal to one (in the case of zero fixed costs) or greater than one. A DOL factor of 1.8 means that for every $10 \%$ change in sales, the operating profit will change by $18 \%$ (all other things being equal).

Similarly, "financial leverage" refers to the effect of interest on debt on profits after interest, given fluctuations in sales. The degree of financial leverage (DFL) is calculated as follows:

$\mathrm{DFL}=$ Operating profit $/$ Profit after interest

The answer is a factor equal to one (no interest) or greater than one and a DFL factor of 1.5 means that for every $10 \%$ change in operating profit, profit after interest changes by $15 \%$ (all other things being equal).

The combined effect, or "total degree of leverage" (TDL), is

$\mathrm{TDL}=\mathrm{DOL} \times \mathrm{DFL}$

or

$\mathrm{TDL}=$ Contribution $/$ Profit after interest

A TDL of $1.8 \times 1.5=2.7$ means for every $10 \%$ change in sales, the profit after interest will change by $27 \%$.

Meditari Accountancy Research Vol. 12 No. 12004 : 39-59 


\subsection{Link between EVA, MVA and leverage}

In Section 2.1 it was indicated that, theoretically, MVA is equal to the present value of all future EVAs. On the assumption that there will be no future growth in the current EVA, or that the expected future growth in EVA will be at a constant rate, g, the theoretical MVA can be calculated as a perpetuity. The result shows that MVA is a multiple of the current EVA.

\section{Example}

Company A has a current EVA of R100m. Its WACC is $20 \%$.

If no future growth in EVA is expected, the theoretical MVA can be calculated as follows:

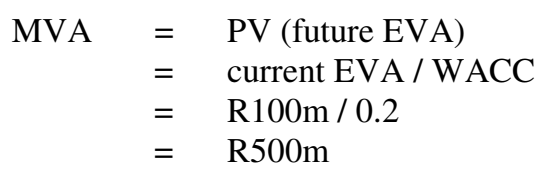

In this instance, MVA is five times the current EVA, or R500/R100m.

If EVA is expected to grow at a constant rate of $10 \%$ in future, the theoretical MVA can be calculated as follows:

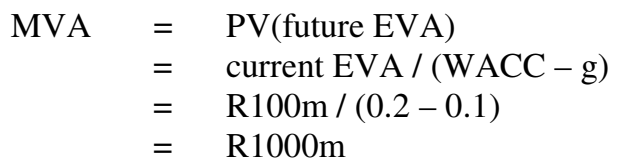

With the assumption of $10 \%$ future growth in EVA, MVA is ten times the current EVA, or (R1000m / R100m). The fact that MVA is theoretically a multiple of the current EVA, means that any percentage change in EVA should cause the same percentage change in MVA.

In section 3 it is shown how the leverage effect of fixed costs and interest cause profits to change more dramatically than sales for a given percentage change in volume. If the cost of equity is subtracted from profits (after interest and tax), one gets EVA. If one assumes that the capital structure and the cost of equity percentage remain unchanged, the amount debited as the cost of equity in the calculation of EVA is a fixed amount. This fixed amount of the cost of equity also has a leverage effect that causes EVA (and the theoretical MVA) to change more dramatically than profits when there are changes in the sales volume. The leverage effect of the cost of equity (referred to as EVA leverage) can now be investigated and combined with operational and financial leverage to study the effect on a business as a whole. 


\section{Research method}

A spreadsheet model was developed using different levels of operating leverage and financial leverage. The relationship between profits (after interest and tax) and EVA was determined. This was done by using the cost of own capital (equity) and this fixed amount can therefore be described as a leverage factor for EVA.

Furthermore, the EVA leverage factor was combined with the operating and financial leverage. It then became possible to illustrate how the expected percentage change in EVA and MVA can be predicted, given a certain percentage change in sales (or profits). The results of the model, using different scenarios (levels of leverage) were than analysed to reach conclusions and to allow some recommendations to be made.

\section{Model assumptions and inputs}

The model assumptions and inputs are contained in Schedule A and are discussed briefly below. It was assumed that a company has "operational assets" consisting of fixed assets and net current assets of R2 million. These are financed by $60 \%$ equity capital and $40 \%$ long-term debt. This model is described as 'average' financial gearing and it is also the optimal capital structure, yielding the lowest WACC of $17.4 \%$. The cost of equity at this level of gearing is assumed to be $22 \%$ and the after-tax cost of debt is $10.5 \%$.

A tax rate of $30 \%$ and a return on assets before tax of $35 \%$ (24.5\% after tax) are assumed. Furthermore, an asset turnover of 1 is assumed; meaning that the total assets of R2 million will yield sales of R2 million. The cost structure of variable costs of $40 \%$ of sales and fixed costs of R500 000 per year is considered "average".

In order to look at the effect of different cost structures (operational leverage), a high fixed cost structure was regarded as one where the variable costs are only $25 \%$ of sales and fixed costs are R800 000 per year. A "low" fixed cost structure was one where the variable costs are $55 \%$ of sales and the fixed costs are R200 000 per year.

The financial structure was also changed to illustrate the effect of different levels of financial leverage. As mentioned above, the optimal structure of $60 \%$ equity and $40 \%$ debt (WACC $=17.4 \%$ ) will be called "average" financial gearing. "High" financial gearing was the situation where $40 \%$ equity and $60 \%$ debt are used, giving a WACC of $18.1 \%$. "Low" financial gearing was indicated by $80 \%$ equity and $20 \%$ debt, also giving a WACC of $18.1 \%$. This points toward the fact that the WACC increases when the financial gearing changes to levels above or below the optimal level.

The model was based on the assumption that operating efficiencies, as indicated by measures such as the asset turnover, remain the same and that there is no inflation. Fixed costs therefore remain the same in total amount and variable costs remain the same percentage of sales.

Meditari Accountancy Research Vol. 12 No. 12004 : 39-59 
Different scenarios (as specified in Schedule A) were created to identify the effects of gearing on profits, EVA and MVA.

\section{Schedule A}

\section{Assumptions and input items}

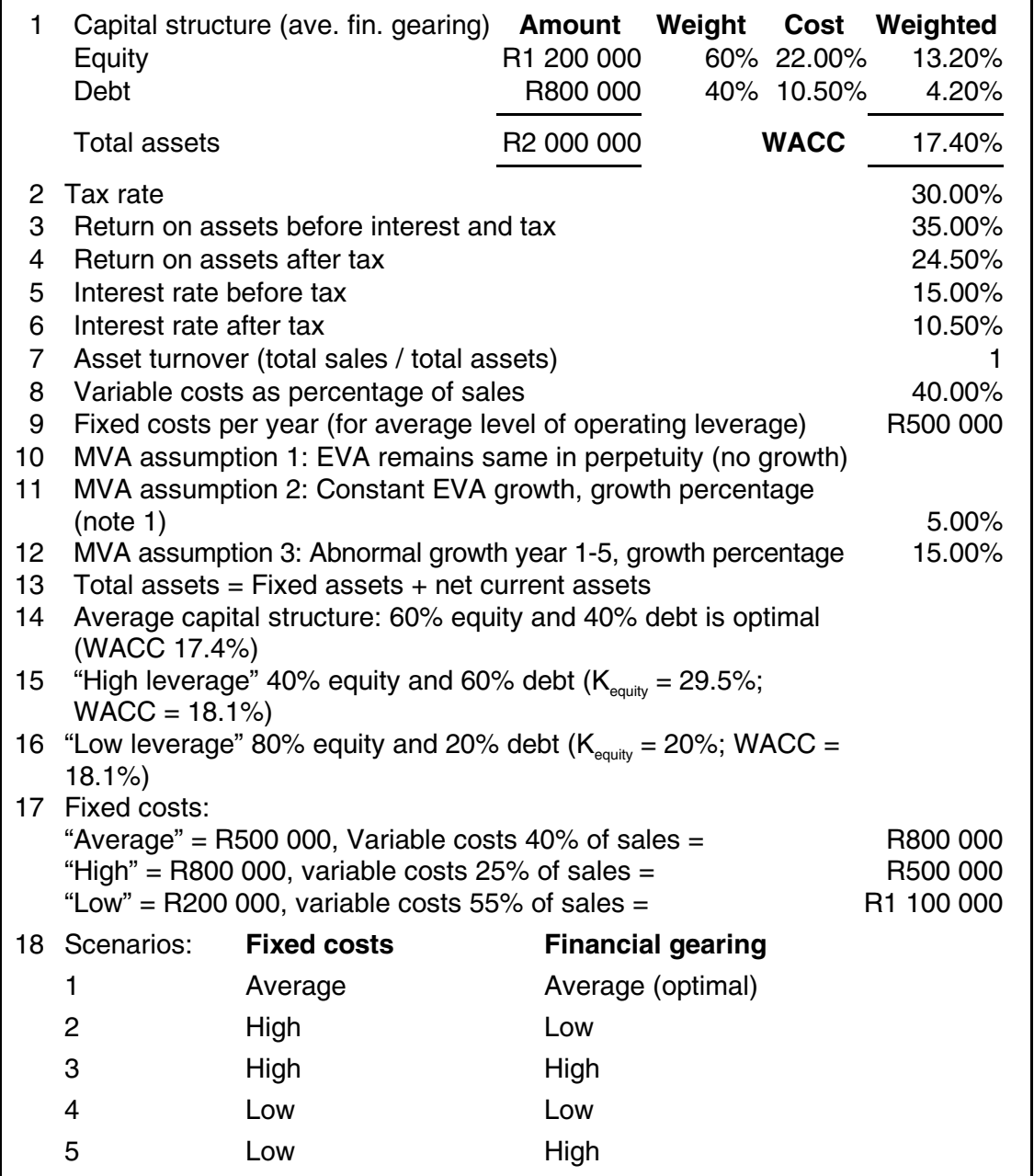

Note 1: If EVA is negative at the outset (base case), constant growth causes EVA to become more negative in future. 


\section{Model output and leverage factors}

Schedule B1 shows the calculation of profits, EVA, MVA as well as the leverage factors for Scenario 1 where average levels of operating leverage and financial leverage are maintained.

$\square$ Sales minus the variable costs give the contribution. When the fixed costs are subtracted from the contribution, the result is Net Operating Profit.

$\square \quad$ Next the interest is subtracted to give Profit Before Tax and after subtracting the tax, the Profit After Tax remains. In order to calculate the EVA, the cost of own capital is subtracted from Profit After Tax.

$\square$ The cost of equity is calculated as $22 \% \times \mathrm{R} 1200000=\mathrm{R} 264000$. An alternative calculation, using the WACC, is used to confirm the EVA.

The MVA is calculated in three ways, allowing for three different assumptions about future growth in EVA. The first version of MVA $\left(\mathrm{MVA}_{1)}\right.$ is calculated as if there will be no future growth in EVA. The calculation is simply:

$\mathrm{MVA}_{1}=$ EVA $/ \mathrm{WACC}$, or R142 $000 / 0.174=\mathrm{R} 816092$.

The second version of MVA $\left(\mathrm{MVA}_{2}\right)$ assumes a constant future growth rate of $5 \%$ in EVA. The calculation is as follows:

$$
\begin{aligned}
\mathrm{MVA}_{2}= & \text { EVA }(1+\mathrm{g}) /(\mathrm{WACC}-\mathrm{g}) \\
& (\mathrm{R} 142000 \times 1.05) /(0.174-0.05)=\mathrm{R} 1202419 .
\end{aligned}
$$

The third version of MVA $\left(\mathrm{MVA}_{3}\right)$ assumes an abnormal growth rate in EVA of $15 \%$ for the first five years and a constant growth rate of 5\% after that. The calculation of $\mathrm{MVA}_{3}$ projects the future EVAs at the abnormal growth rate of $15 \%$ for the first 5 years and then at $5 \%$ in perpetuity.

$$
\begin{aligned}
\mathrm{MVA}_{3}= & \mathrm{R} 142000(1.15) / 1.174+\mathrm{R} 142000(1.15)^{2} / 1.174^{2}+ \\
& \mathrm{R} 142000(1.15)^{3} / 1.174^{3}+\mathrm{R} 142000(1.15)^{4} / 1.174^{4}+ \\
& \mathrm{R} 142000(1.15)^{5} / 1.174^{5}+\left[\mathrm{R} 142000(1.15)^{5} \times(1.05) /\right. \\
& (0.174-0.05)] / 1.174^{5} \\
= & \mathrm{R} 1752063 .
\end{aligned}
$$

As a check for the reasonableness of this calculation, the total market value of equity was calculated and divided by the book value to give the Market : Book ratio. The ratios calculated for all three versions of MVA range from 1.68 to 2.46 and are considered reasonable. Another test for reasonableness is the MVA/EVA multiple. It ranges from 5.75 for $\mathrm{MVA}_{1}$ to 12.34 for $\mathrm{MVA}_{3}$. This is in line with the research findings of Stern Stewart, cited by Ehrbar (1998:78) namely that "each $\$ 1$ increase in EVA brings, on average, a $\$ 9.50$ increase in MVA." 


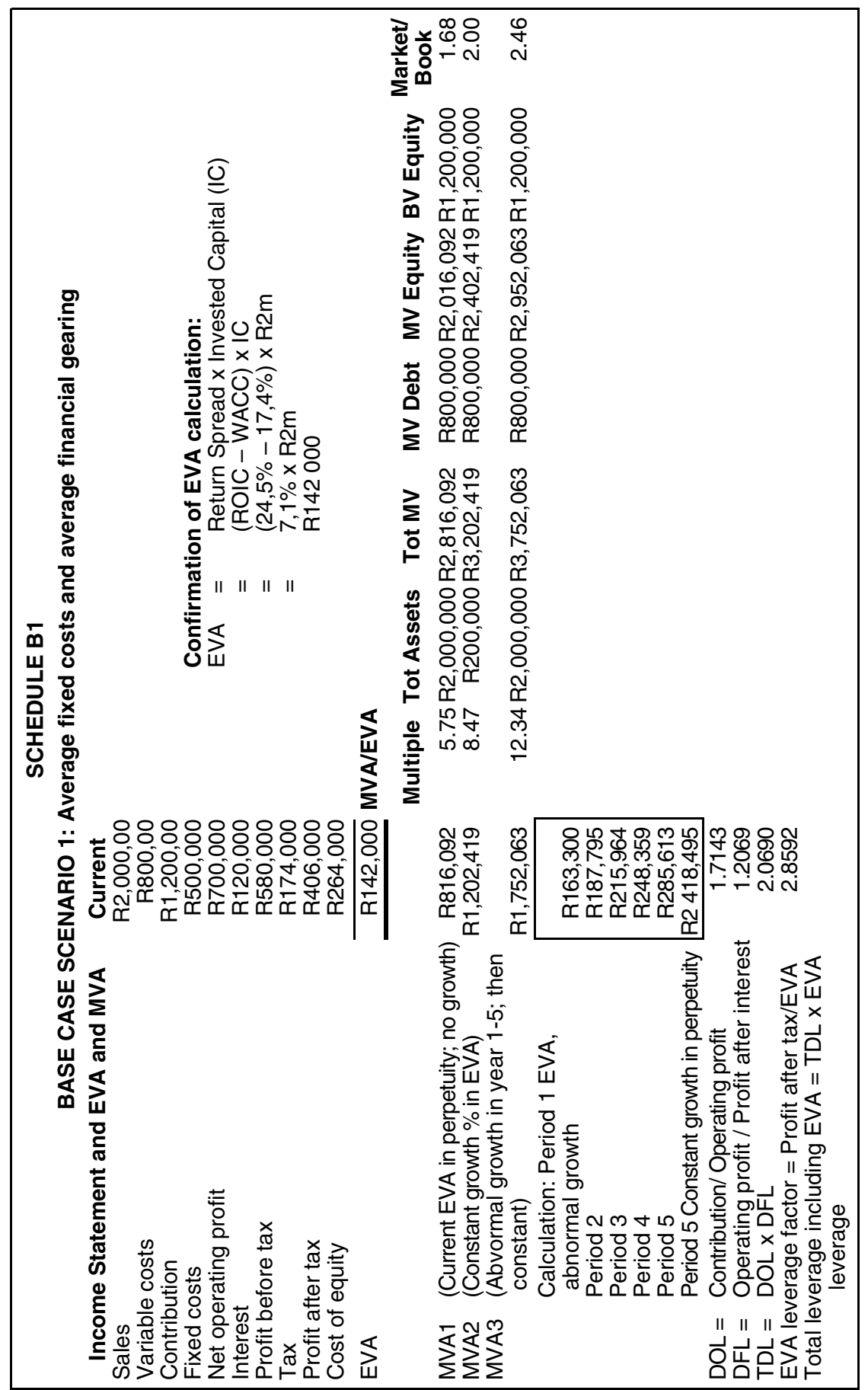




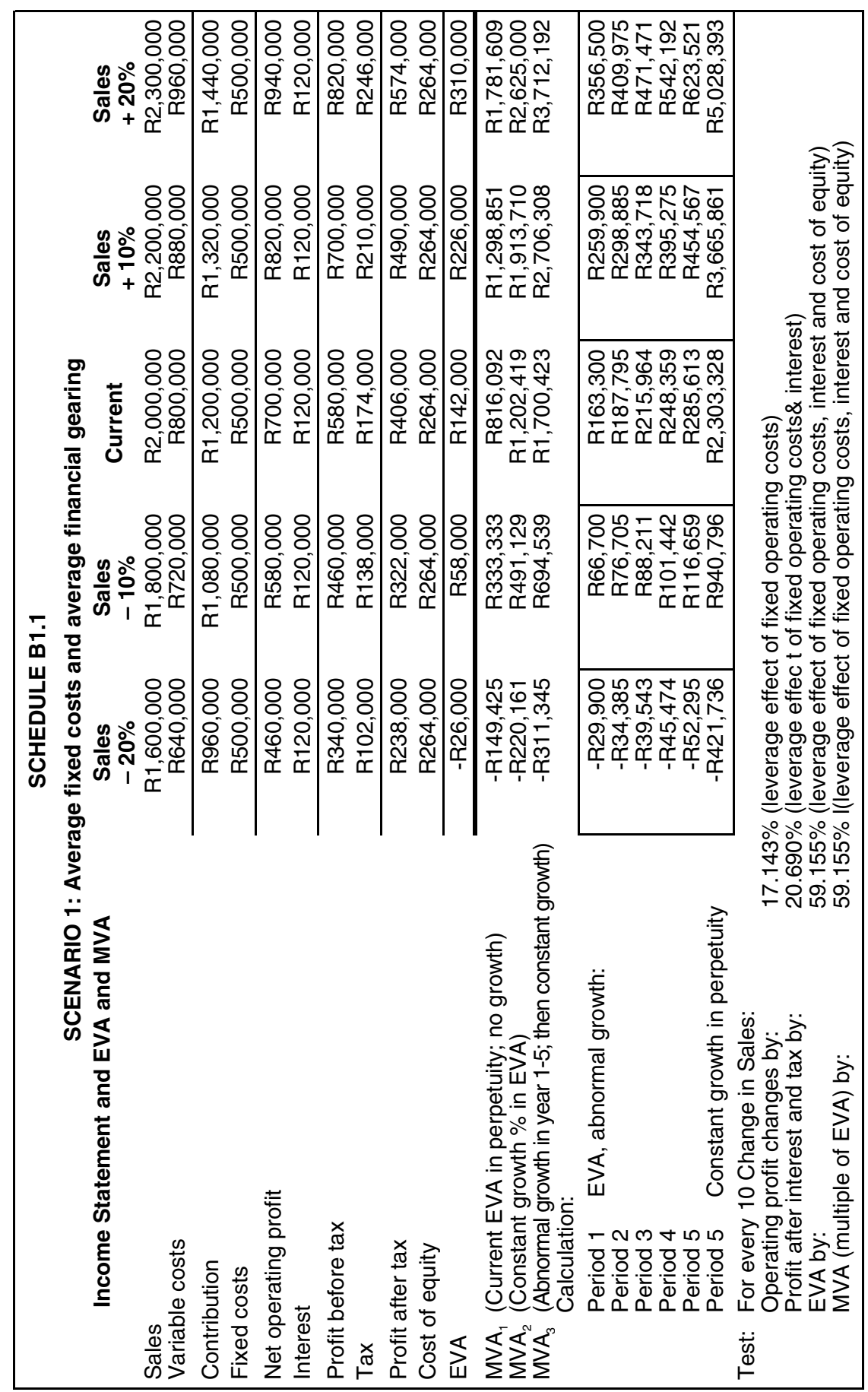

Meditari Accountancy Research Vol. 12 No. 12004 : 39-59 


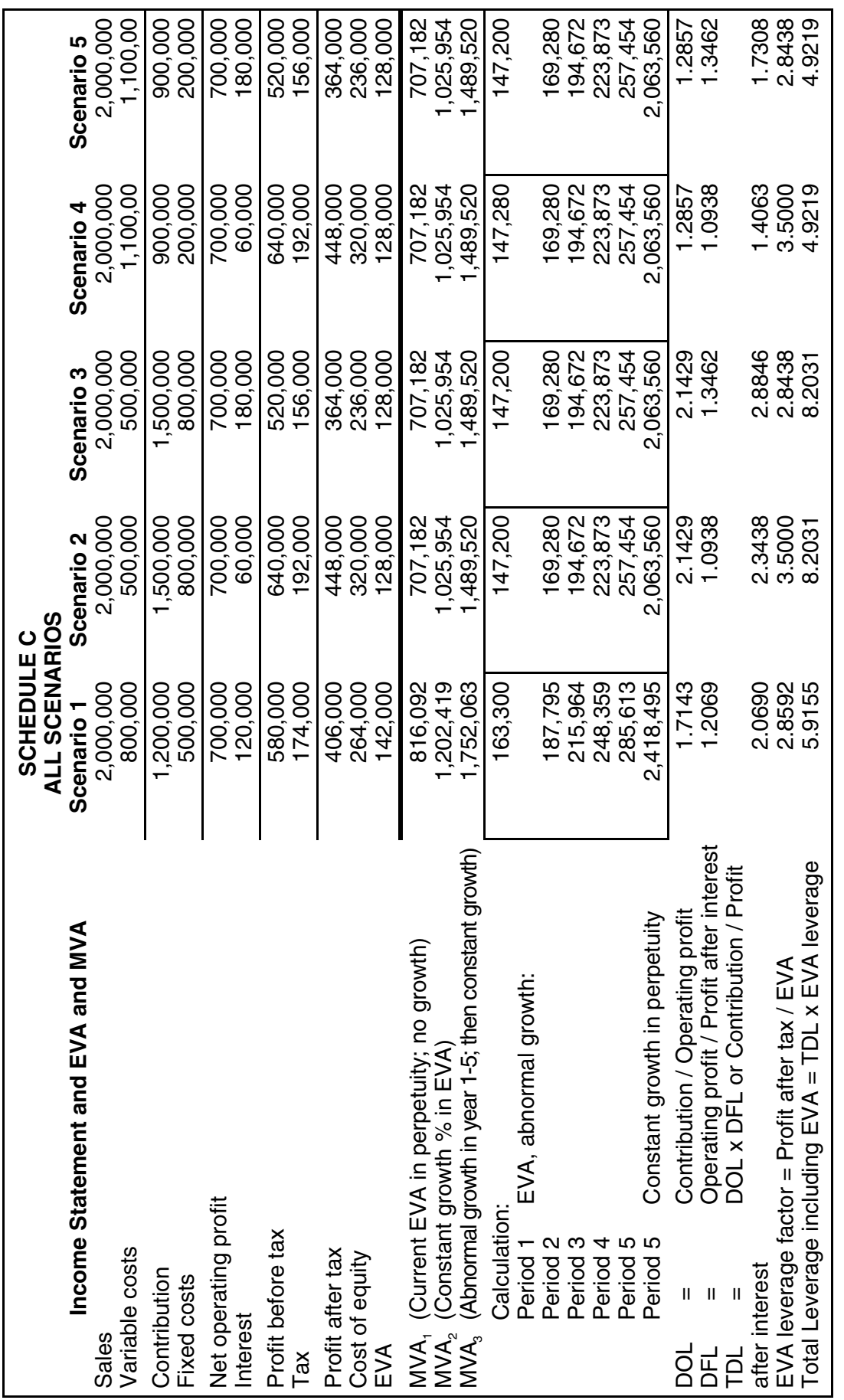


The leverage factors were calculated as follows:

$$
\begin{aligned}
\text { Degree of Operating Leverage (DOL) } & =\text { Contribution/Operating Profit } \\
& =1200000 / 700000 \\
& =1.7143
\end{aligned}
$$

This means that for every $1 \%$ change in sales (or contribution), the Operating Profit changes by $1.7143 \%$.

$$
\begin{aligned}
\text { Degree of Financial leverage (DFL) } & =\text { Operating Profit/Profit after Interest } \\
& =700000 / 580000 \\
& =1.2069
\end{aligned}
$$

This means that for every $1 \%$ change in Operating Profit, Profit After Interest changes by $1.2069 \%$.

$$
\begin{aligned}
\text { Total Degree of Leverage }(\mathrm{TDL}) & =\mathrm{DOL} \times \mathrm{DFL} \\
& =1.7143 \times 1.2069 \\
& =2.0690
\end{aligned}
$$

This means that for every $1 \%$ change in sales (or contribution) the Profit After Interest changes by $2.0690 \%$.

When EVA is calculated, the cost of own capital is a fixed charge that also represents a leverage factor that causes the EVA and MVA to fluctuate more drastically than a given percentage change in sales. This "EVA" leverage effect is caused by the cost of own capital (equity) and is calculated as follows:

EVA leverage

$$
\begin{aligned}
& =\text { Profit after interest and tax/EVA } \\
& =406000 / 142000 \\
& =2.8592
\end{aligned}
$$

This means that for every $1 \%$ change in profit after interest and tax, EVA will change by $2.8592 \%$. If this is combined with the TDL already calculated, then

Total leverage including EVA

$$
\begin{aligned}
& =\text { TDL } \times \text { EVA leverage factor, or } \\
& =\text { Contr. } \times(1-\text { tax rate }) / \text { EVA } \\
& =2.0690 \times 2.8592 \\
& =5.9155
\end{aligned}
$$

This means that for every $1 \%$ change in sales (or contribution), EVA (and MVA) changes by $5.9155 \%$. Because MVA is a multiple of EVA, the percentage change in MVA is the same as that for EVA, given a certain percentage change in sales.

In Schedule B1.1 the effect of changes of $-20 \% ;-10 \% ;+10 \%$ and $+20 \%$ on sales was calculated to verify the correctness of the leverage factors for Scenario 1. The inputs of the spreadsheet set out in Schedule A were then changed for each of the other scenarios ( 2 to 5). The results are summarised in Schedule C. Due to the repetitive nature of the exercise for each scenario, the equivalent spreadsheets for the other scenarios (what would have been B2.1, B3.1, B4.1 and B5.1) are not included here.

Meditari Accountancy Research Vol. 12 No. 12004 : 39-59 


\section{Results of the analysis}

The different levels of operating leverage for each of the five scenarios are set out in Figure 1. It is obvious that the operational leverage factors (as a result of fixed costs) are highest for Scenarios 2 and 3. Figure 2 shows the DFL for each scenario. Scenarios 3 and 5 stand out as those with the highest DFL (on account of their high level of long-term debt).

Figure 1 Degree of operational leverage (DOL) for each scenario

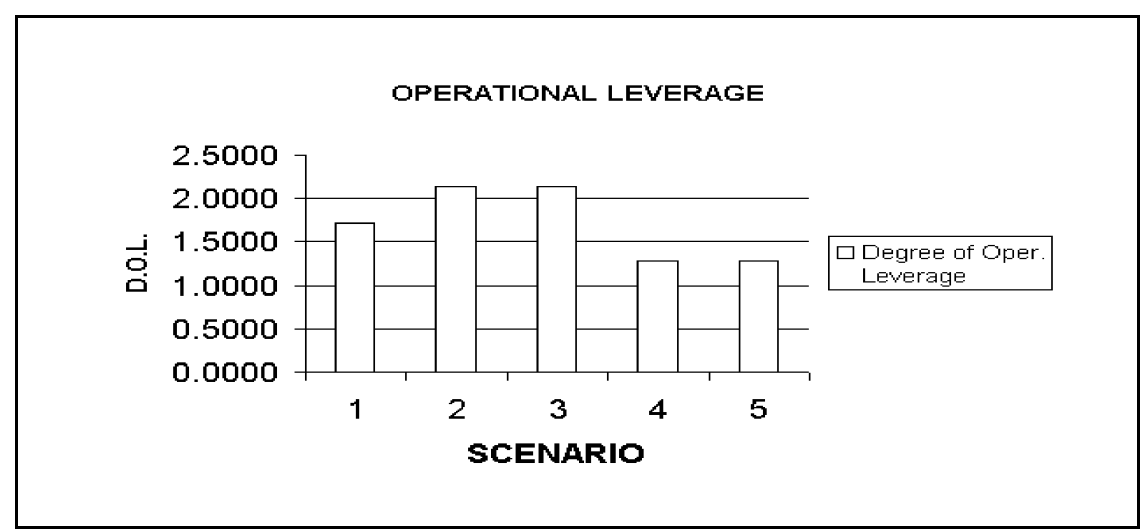

\section{Summary}

Scenario 1

Fixed costs Debt

Fixed costs Debt

Scenario 2

Average

Average

Scenario 4 Low

Low

Scenario 3

High

Low

Scenario 5 Low

High

High High 
Figure 2 Degree of financial leverage (DFL) for each scenario

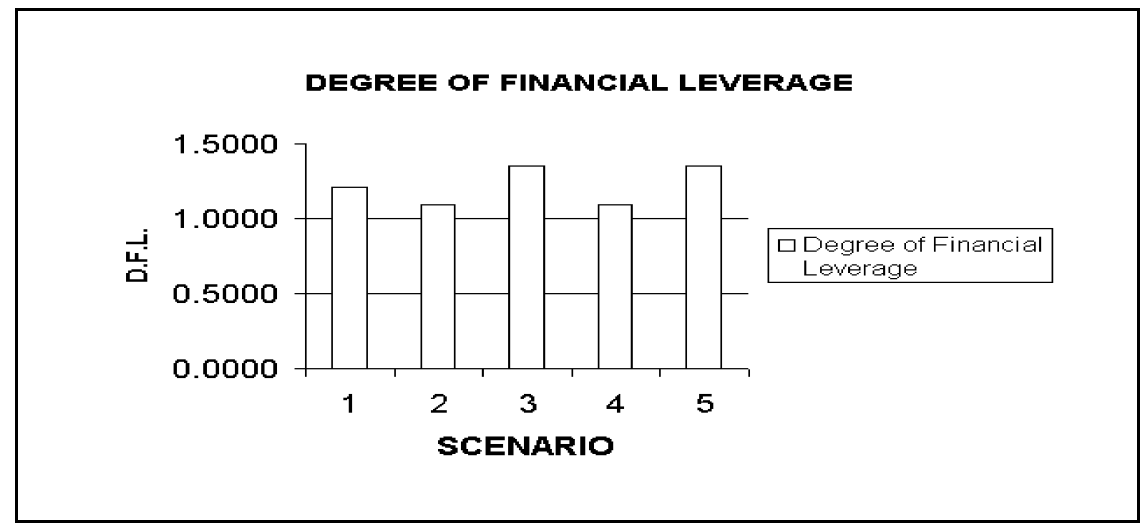

As the degree of EVA leverage is dependent on the size of own (equity) funding, one would expect this leverage factor to contrast with the financial leverage situations. This expectation is borne out by Figure 3, which shows that the degree of EVA leverage is indeed highest for those scenarios where the financial gearing is low, namely Scenarios 2 and 4. It is interesting to note that the Degree of EVA leverage is the same for the same level of financial gearing, Scenarios 2 and 4 (high) and Scenarios 3 and 5 (low).

Figure 3 Degree of EVA leverage for each scenario

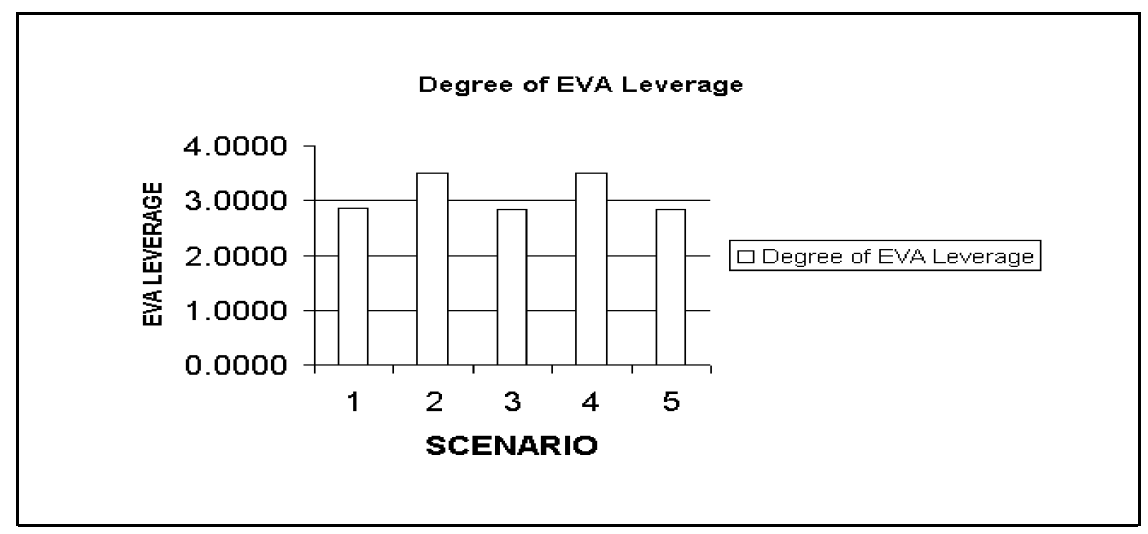


Figure 4 Total leverage including EVA for each scenario

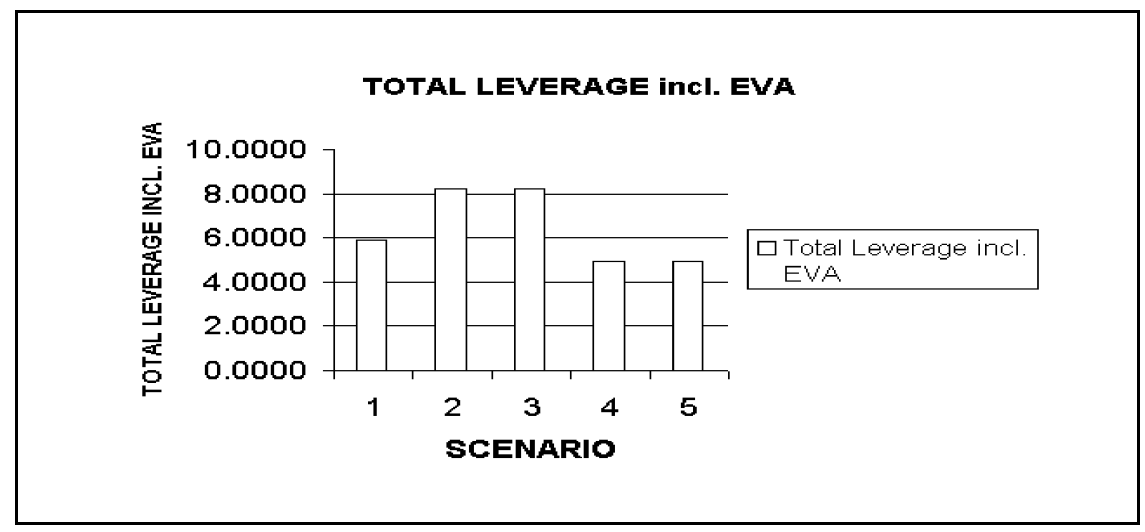

Figure 4 shows the total degree of leverage, including EVA. The scenarios with the highest total leverage, including EVA factors, are Scenarios 2 and 3, which interestingly enough also have the highest levels of fixed costs. Furthermore, the total leverage including EVA factors is considerably lower for scenarios with low fixed costs, such as Scenarios 4 and 5. In addition, the factors are the same for scenarios with the same level of fixed costs, namely Scenarios 2 and 3 (high) and Scenarios 4 and 5 (low). From this one can conclude that the total degree of leverage including EVA is not affected by the financial gearing, but only by the operational gearing (given that the WACC is the same for the different levels of financial gearing).

Figure 5 Effect of changes in sales on net operating profit

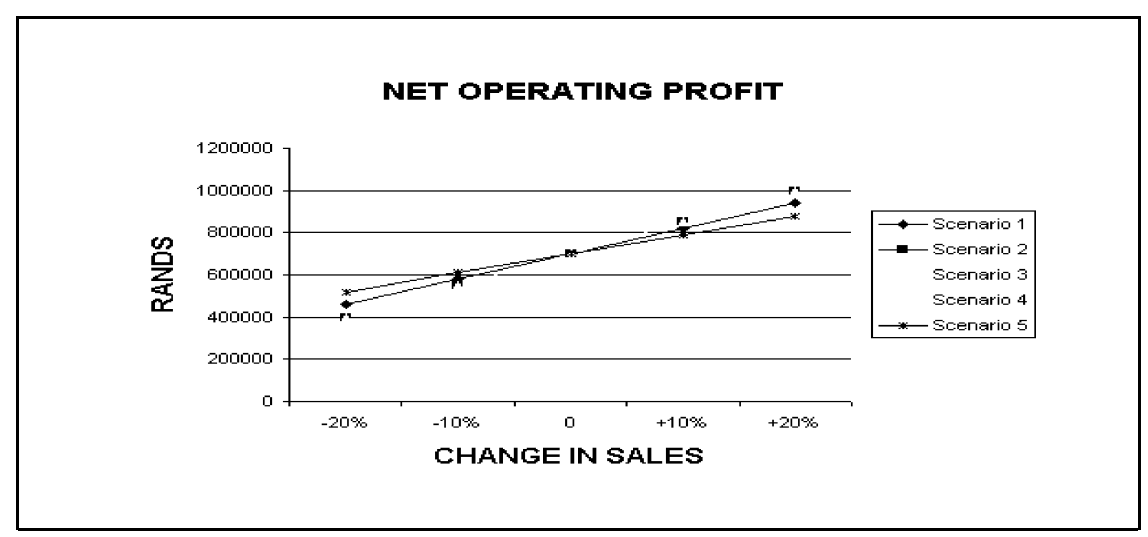


Figure 6 Effect of changes in sales on profit after tax and interest

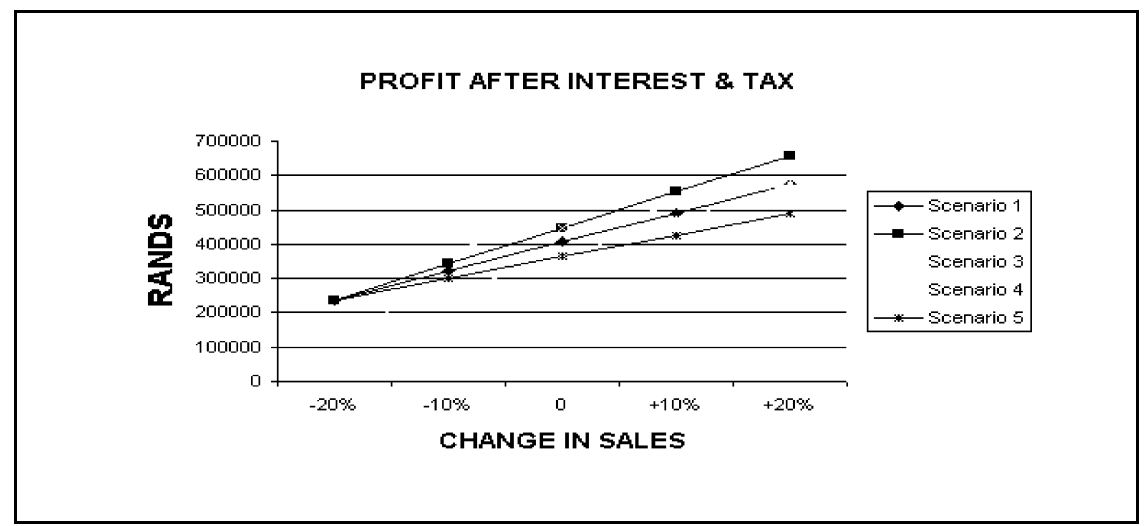

Figure 5 indicates the effect of operational leverage. It shows that the effect of a change in sales is more drastic for scenarios with higher fixed costs, namely Scenarios 2 and 3, than for the other scenarios. Figure 6 shows the combined effect of operational leverage and financial leverage on profit after interest and tax. As expected, the greatest volatility was found in the scenarios with the highest total degree of leverage, namely Scenarios 2 and 3.

\section{Figure 7 Effect of changes in sales on EVA}

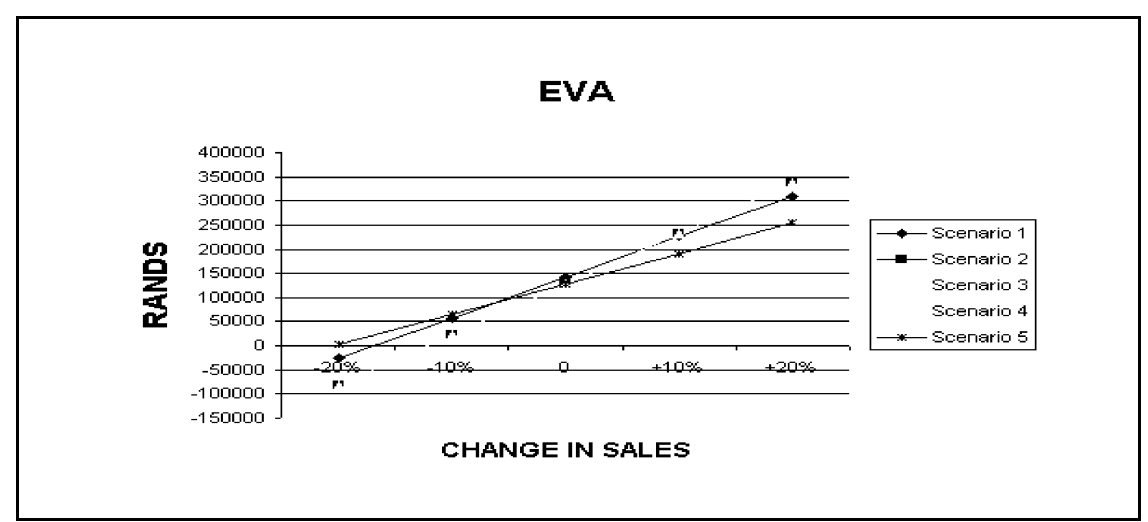


Figure 8 Effect of changes in sales on MVA

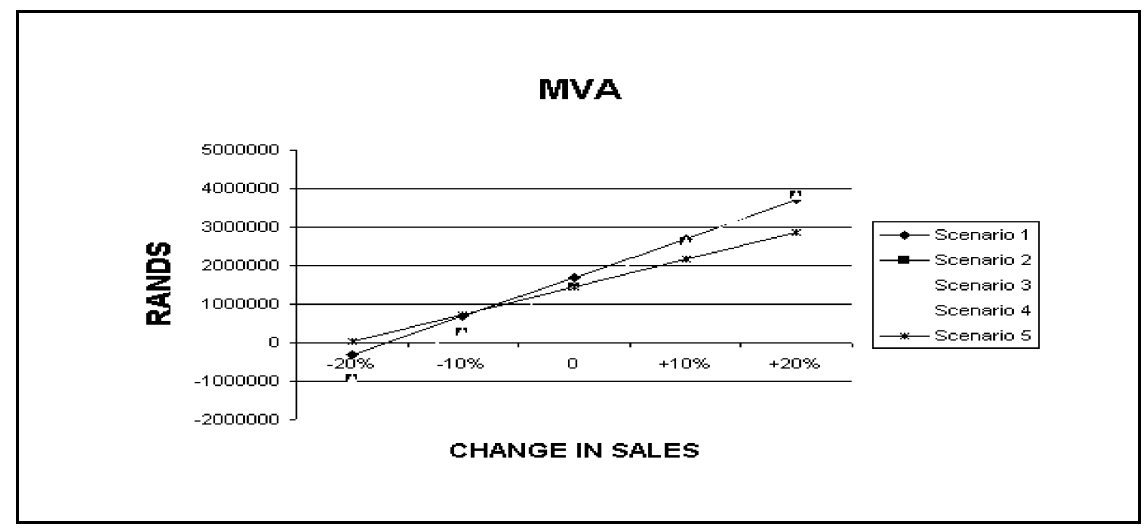

Figure 7 shows the effect of changes in sales on EVA. As expected, the scenarios with the highest total leverage including EVA, namely Scenarios 2 and 3, showed the greatest volatility in EVA for changes in sales. Finally, Figure 8 shows the effect of changes in sales on $\mathrm{MVA}_{3}$. Again, the scenarios that were the most volatile were the ones with the highest total leverage including EVA, namely Scenarios 2 and 3.

\section{Conclusions}

The spreadsheet model was used to investigate the leverage effect of three items, namely fixed costs (DOL), interest on borrowed capitaI (DFL) and the cost of own capital (EVA leverage). Five different scenarios, each with a different level of DOL, DFL or EVA leverage, were assumed to determine the relationships (if any) between the different kinds of leverage as well as their impact on profits, EVA and MVA (and therefore, also the value of the firm).

The results indicated that the size of the total level of leverage including EVA is determined by all three elements causing the leverage. However, there was no difference in the total leverage including EVA for scenarios where only the financial gearing differed. The analysis showed that the effect of high financial leverage is offset perfectly by the lower cost of own capital (EVA leverage). Stated differently, the total leverage including EVA is the same for all scenarios with the same fixed costs (only if WACC remains constant).

Given the assumptions made, one can conclude that the organisation's sensitivity to changes in sales volume is determined by its degree of operational leverage and by its total cost of capital (as represented by the financial leverage and EVA leverage). The way the company is financed (assuming there is no change in the WACC) will not affect this total leverage effect. 


\section{Recommendations}

Using the information for Scenario 1 and assuming sales volume can be increased by 5\% without an increase in assets, the expected effect on the share price can be determined as follows:

If it is assumed that the number of ordinary shares is 120000 , the share price based on Scenario 1 in Schedule B1 is R2 $952063 / 120000=\mathrm{R} 24,60$

$\begin{array}{lll}\text { Increase in sales volume } & & 5 \% \\ \text { Total leverage factor } & & 5,9155 \\ \text { Increase in EVA and MVA } & 5 \% \times 5,9155 & =29,57 \% \\ \text { New } \mathrm{MVA}_{3} \text { (Schedule B1) } & \mathrm{R} 1752063 \times 1,2957 & =\mathrm{R} 2270148 \\ \text { New total market value } & \mathrm{R} 2000000+\mathrm{R} 2270148 & =\mathrm{R} 4270148 \\ \text { Market value of equity } & \mathrm{R} 4270148-\mathrm{R} 800000 & =\mathrm{R} 3470148 \\ \text { New price per share } & \mathrm{R} 3470148 / 120000 & =\mathrm{R} 28,92\end{array}$

All other things being equal, a 5\% increase in sales volume would lead to an increase of $17,56 \%$ in the share price.

It is recommended that companies make use of the suggested spreadsheet model in order to investigate and analyse the effects of changes in sales and other input items (such as selling prices, costs and the cost of capital) on the crucial performance measures of EVA and MVA. As illustrated, these changes in EVA and MVA represent a direct quantification of shareholder value creation. The techniques discussed can be applied in performance measurement, valuations, cost/volume/profit analysis, sensitivity analysis, value management and scenario planning. The techniques can even be used to develop a performance-based reward system for all employees of a company that creates value for its shareholders.

Further research could focus on the effect that other factors, such as changes in the financial structure and costs, would have on EVA and MVA. Empirical studies could be conducted by using the data of listed companies to investigate these leverage effects in practice, and by using the suggested spreadsheet model. 


\section{Bibliography}

Brealy, R.A. and Myers, S.C. 2000. Principles of Corporate Finance, Irwin, Burr Ridge, Illinois.

Copeland, T.E., Koller, T. and Murrin, J. 1996. Valuation: Measuring and Managing the Value of Companies, 2nd edition, Wiley, New York.

Copeland, T. 2002. Want to create value?, Strategic Finance, March 2002, Vol. 83, No. 9, pp.48-54.

Correia, C., Flynn, D., Uliana, E. and Wormald, M. 2003. Financial Management, 5 th edition, Juta, Cape Town.

Davidson, S. 2003. Analysis Tools Help Improve Bank Performance and Value, Community Banker, February 2003, pp.48-50.

Ehrbar, A.L. 1998. EVA - The Real Key to Creating Wealth, John Wiley, New York.

Ernst \& Young. 1994. EVA as a management tool, From 'In Touch', reprinted in Accountancy SA, June 1994, p.10.

Firer, C. 1995. Investment Basics $X X X E V A^{T M}$ : the real key to creating value, Investment Analysts Journal, Summer 1995, No. 40, pp.57-59.

Garrison, R.H., Noreen, E.W. and Seal, W. 2003. Management accounting European edition, McGraw-Hill, New York.

Gates, S. 2000. Strategic performance measurement systems: translating strategies into results, Journal of Applied Corporate Finance, Fall, Vol. 13, No. 3, pp.44-59.

Gitman, L.J. 2000. Principles of Managerial Finance, 9th edition, Addison Wesley Longman, Boston.

Grant, J.L. 1997. Foundations of Economic Value Added, Frank Fabozzi, New Hope.

Hall. J.H. 1998. Variables determining shareholder value of industrial companies listed on the Johannesburg Stock Exchange, Doctoral thesis, University of Pretoria, Pretoria.

Hatfield, G.R. 2002. R\&D in an EVA world, Research Technology Management, Jan/Feb 2002, Vol. 45, No. 1, pp.41-47.

Hawawini, G. and Viallet, C. 1999. Finance for Executives, Thomson Publishing, Cincinnati.

Horngren, C.T., Datar, S.M. and Foster, G. 2003. Cost accounting - A managerial emphasis, 11th edition, Prentice-Hall, New York.

Johnson, W.B., Natarajan, A. and Rappaport, A. 1985. Shareholder Returns and Corporate Excellence, Journal of Business Strategy, pp.52-62.

Keef, S. and Roush, M. 2002. Does MVA measure up?, Financial Management, January 2002, pp.20-21. 
Kramer, J.K. and Peters, J.R. 2001. An inter-industry analysis of Economic Value Added as a proxy for Market Value Added, Journal of Applied Finance, pp.41-49.

Lehn, K. and Makhija, A.K. 1996. EVA and MVA as performance measures and signals for strategic change, Strategy \& Leadership, May/June 1996, pp.34-38. Rappaport, A. 1986. Creating Shareholder Value, The Free Press, New York.

Reilly, F.K. and Brown, K.C. 2003. Investment analysis portfolio management, 7th edition, Thomson-South Western, Cincinnati.

Ross, S.A., Westerfield, R.W., Jordan, B.D. and Firer, C. 1999. Fundamentals of Corporate Finance, 1st South African edition, McGraw-Hill, Roseville.

Stern, J. 1993. Value and People Management, Corporate Finance, July 1993, pp.35-37.

Stewart, G.B. III 1991. The Quest for Value, Harper-Collins, New York.

Weston, F.J. and Copeland, T.E. 1992. Managerial Finance, 9th edition, Dryden Press, New York. 